\title{
Eosinophil oesophagitis étrendi és gyógyszeres vonatkozásai
}

\author{
Kocsis Dorottya dr. - Tulassay Zsolt dr. - Juhász Márk dr. \\ Semmelweis Egyetem, Általános Orvostudományi Kar, II. Belgyógyászati Klinika, Budapest
}

\begin{abstract}
Az eosinophil oesophagitis a nyelőcső krónikus, antigénmediált gyulladása. A nyelőcsőben orális és/vagy aeroantigének által indukált eosinophilgranulocyta-infiltráció, nyálkahártya-hyperplasia és a subepithelialis rétegek fibrosisa szükülethez, dysphagiához és falatelakadáshoz vezethet. A betegség gyakran társul más allergiás kórképekkel, mint az asthma vagy az atopiás dermatitis. Az eosinophil oesophagitis kezelésének sarokkövei az elkerülő diéta és a helyileg alkalmazott, gyulladáscsökkentő szteroidkezelés. A szerzők áttekintik a jelenleg rendelkezésre álló kezelési stratégiákat. Orv. Hetil., 2015, 156(23), 927-932.
\end{abstract}

Kulcsszavak: eosinophil oesophagitis, dysphagia, allergia, diéta

\begin{abstract}
Dietary and pharmacological aspects of eosinophilic esophagitis
Eosinophilic esophagitis is considered to be a chronic antigen-driven disease whereby food and/or aeroallergens induce a chronic inflammatory infiltrate in the esophagus leading to pathological hyperplasia of the epithelial and muscular layers, fibrosis of the lamina propria and symptoms of dysphagia and food impaction. Eosinophilic esophagitis is often associated with other allergic diseases such as asthma or atopic dermatitis. Current first line treatments of the disease include strict dietary modification and topical anti-inflammatory steroids. In this review the authors summarize currently available treatment strategies of eosinophilic esophagitis.
\end{abstract}

Keywords: eosinophilic esophagitis, dysphagia, allergy, diet

Kocsis, D., Tulassay, Zs., Juhász, M. [Dietary and pharmacological aspects of eosinophilic esophagitis]. Orv. Hetil, 2015, 156(23), 927-932.

(Beérkezett: 2015. március 11.; elfogadva: 2015. április 16.)

\begin{abstract}
Rövidítések
$\mathrm{ECP}=$ eosinophil kationos protein; EDN $=$ eosinophil eredetü neurotoxin; EoE = eosinophil oesophagitis; $\mathrm{EPO}=$ eosinophil peroxidáz enzim; IFN- $\gamma=$ interferon- $\gamma ; \mathrm{MBP}=$ main basic protein; $\mathrm{MMP}=$ mátrixmetalloproteáz; TGF $=$ tumor growth factor; TNF- $\alpha$ = tumornekrózis-faktor- $\alpha$
\end{abstract}

\section{Epidemiológia}

$\mathrm{Az}$ eosinophil oesophagitis (EoE) az utóbbi 15 évben kap megkülönböztetett figyelmet, mint önálló kórkép, azóta számos tanulmány vizsgálta előfordulási gyakoriságát [1]. A betegség leggyakrabban gyermekkorban vagy fiatal felnőttkorban jelentkezik [2]. Noel és mtsai 20002003 között az ohiói gyermekpopulációban vizsgálva az EoE-prevalenciát 4/100 000, az EoE-incidenciát 0,9-
1,3/100 000-nek találták [3]. Egy 16 éven át tartó svájci tanulmány hasonló prevalenciát $(2 / 100000)$ és incidenciát $(1,4 / 100000)$ figyelt meg felnőtt betegek körében [4]. Huszonöt, gyermekek körében végzett epidemiológiai vizsgálat eredményét összevetve, Soon és $m$ tsai az EoE prevalenciáját $0,2-43 / 100000$, incidenciáját $0,7-10 / 100000$ közé teszik [5]. Felnőttek körében végzett vizsgálatok is hasonló eredményekről számoltak be $[6,7,8]$. EoE legtöbbször a kaukázusi rasszban jelentkezik, a férfi:nő arány 3:1 [2]. Több kutatás szezonális eltérést írt le az EoE tüneteinek előfordulási gyakoriságában, ami valószínúsíti az aeroallergének szerepét a kórkép kialakulásában [9]. Emellett szól még, hogy a betegek 28,6-85\%-ának anamnézisében szerepel allergiás rhinitis, sinusitis, asthma vagy atopiás dermatitis [10]. 


\section{Patogenezis és klinikum}

Az EoE kialakulásában a genetikai prediszpozíció és a környezeti faktorok egyaránt szerepet játszanak. A genetikai meghatározottságot bizonyítja az EoE családi halmozódása: Noel és mtsai 103 gyermeket vizsgáltak, a betegek 6,8\%-ának családi anamnézisében volt kimutatható dysphagia. Beteg egyének testvéreiben a betegség kialakulási kockázata közel 80-szoros az átlagpopulációhoz képest [11]. Az EoE-val összefüggésbe hozható gének: az EoEben fokozott expressziót mutató CCL26/eotaxin-3 gén, valamint az 5. kromoszóma hosszú karján elhelyezkedő TSLP és WD36 gének. A TSLP gén a Th2-válasz-szabályozásban részt vevő, interleukin-7-hez hasonló (IL-7 similar) citokint kódol, míg a WD36 gén által kódolt fehérje a T-sejt-aktivációban játszik szerepet, és összefüggésbe hozták glaucoma kialakulásával is [12, 13].

Genetikailag fogékony egyénekben az orális és/vagy aeroantigének triggerelőhatását teszik felelőssé az EoE kialakulásáért. A legtöbb EoE-betegnél igazolható valamilyen, emelkedett szérum-IgE-szinttel járó, étel vagy aeroallergén iránti túlérzékenység $[14,15]$. Ételallergia lehetôsége az EoE-vel diagnosztizált gyermekek 1973\%-ánál, a felnőtt betegek 13-25\%-ánál merült fel. A leggyakoribb ételallergének a tej, tojás, szója, búza, árpa, zab, rozs, rizs, kukorica, burgonya, babfélék, mogyorófélék, marhahús, csirkehús, tenger gyümölcsei [16, 17].

A felnőtteknél tapasztalt ételallergén iránti kisebb fokú túlérzékenység oka még nem tisztázott, ez egyben azt is jelenti, hogy a felnőtt, EoE-ben szenvedők kevésbé reagálnak az ételallergéneket elimináló elkerülő diétára [18]. Az EoE-vel gyakran társuló atopiás kórképek, allergiás légúti megbetegedések és a betegség tüneteinek évszakhoz kötött változékonysága az aeroallergének, leginkább a pollenek a kórkép kialakításában játszott szerepére utal $[8,9,10]$.

EoE-ben a gyulladásos folyamatot a fokozott Th2-válasz indítja be. Az allergéneket az antigén-bemutató sejtek prezentálják a T-lymphocytáknak, a találkozást követően a T-sejtek Th2-sejtekké alakulnak, majd különböző citokinek túltermelése révén (IL-5) fokozzák a csontvelőben az eosinophil granulocyták és hízósejtek termelödését [18, 19]. A hízósejtek szerepe még nem teljesen tisztázott az EoE kialakulásának folyamatában, állat- és humán modellek alapján valószínúsítik, hogy a hízósejtek által termelt proteoglikánok, mint a heparin, potencírozzák az eotaxinindukált eosinophilgranulocyta-toborzást. Az epithelsejtek fokozott eotaxin-3-termelése az eosinophil granulocyták kemokinreceptor-3-on kifejtett hatása révén befolyásolja azok mozgását és aktivációját, ez a folyamat lesz felelős az eosinophil granulocyták nyelőcsőbe vándorlásáért [20]. Az eosinophil granulocyták, a nyelőcsőben aktiválódva, granulumaiból eosinophil kationos protein (ECP), main basic protein (MBP), eosinophil peroxidáz enzim (EPO) és eosinophil eredetű neurotoxin (EDN) szabadul fel, károsítva a környező szöveteket, beindítva a gyulladásos válaszreakciót.
Az eosinophil eredetű érképződési molekulák (VCAM1) fokozzák az erezettséget és megkönnyítik a gyulladásos sejtek toborzását. A TGF-ß és mátrixmetalloproteáz-9 (MMP-9) indukálják a szövetek fibroticus átalakulását. Az MMP-9 és az MBP lesz felelős az oesophagusepithel integritásának zavaráért [18, 21].

Érdekes módon a Th2-sejtek által termelt citokinek mellett a Thl citokinek közé tartozó tumornekrózisfaktor- $\alpha($ TNF- $\alpha)$ és interferon- $\gamma($ IFN- $\gamma)$ szintjét is emelkedettnek találták EoE-betegek nyelőcső-biopsziás mintáinak vizsgálata során, ami utalhat a nem IgE-mediált IV. típusú (sejtközvetített) túlérzékenységi reakció EoEben játszott szerepére $[15,22]$.

Az EoE-betegek a tünetek széles skáláját mutathatják, a klinikai megjelenés eltérő lehet, attól függően, hogy a kórkép milyen életkorban alakult ki.

Két év alatti gyermekekben az EoE táplálási nehézség, folyadék vagy szilárd étel adását követő fulladásos tünetek, növekedéselmaradás formájában jelentkezik. A 2-12 év közötti gyermekeknél GORB-szerü tünetek - hányinger, hányás, hasi fájdalom, gyomorégés, regurgitatio - a leggyakoribbak. A nyelési zavar, falatelakadás, mellkasi fájdalom gyakorisága a kor előrehaladtával növekszik $[23,24]$.

Felnőttekben az EoE legjellemzőbb tünete az időszakosan jelentkező dysphagia és falatelakadás. Nem ritka, hogy a betegek a tünetek hatására módosítják étkezési szokásaikat (lassabban étkeznek, kerülik a száraz, érdes felületű ételeket, a szilárd ételt csak folyadékkal együtt tudják fogyasztani). Felnőtteknél is gyakori tünet lehet a hányinger, hányás vagy mellkasi fájdalom, valamint hasmenés és súlyvesztés is előfordulhat $[23,25,26]$.

Mindemellett az EoE-betegek 10-25\%-ánál fennállhatnak atipikus GORB-tünetek: rekedtség, köhögés, sinusitis, alvás alatti légzészavarok [27]. EoE súlyos szövődménye lehet a spontán nyelősső-perforáció. Az EoE-nek nincs a diagnózist egyértelmúen meghatározó specifikus tünete, ugyanakkor időszakosan jelentkező dysphagia, falatelakadás, gyógyszeres kezelésre nem reagáló GORBszerü tünetek esetén mindig gondolni kell rá [28].

\section{Diagnosztika}

Az EoE két fő diagnosztikus eszköze az endoszkópia és szövettan, emellett az allergiatesztek, a pH-monitorozás, az endoszkópos ultrahangvizsgálat, manometriai vizsgálatok és a nyelésröntgen is segítheti a diagnózis felállítását.

\section{Endoszkópia}

EoE gyanúja esetén az első diagnosztikus lépés a felső panendoszkópia és oesophagus-mintavétel. EoE fennállására a nyelőcső számos endoszkópos elváltozása utalhat, ezek közé tartozik a kis, fehéres, pont- vagy vonalszerü exudatum, nyálkahártya-oedema, nyálkahártya-barázdák, gyưrúképződés, krepp-papír-, utcakő- vagy 


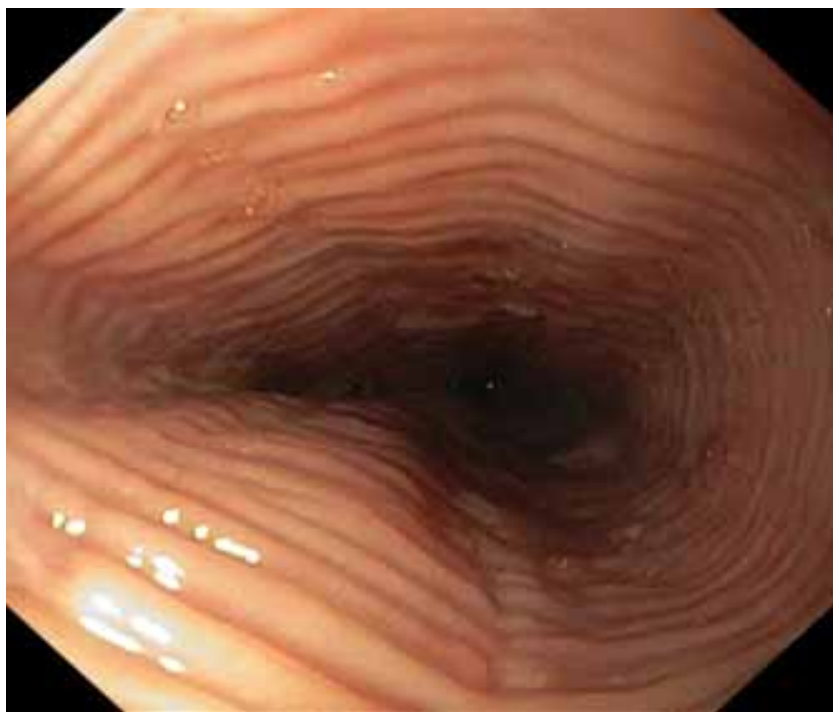

1. ábra

Eosinophil oesophagitis felső panendoszkópos képe: gyưrúkép-
ződés

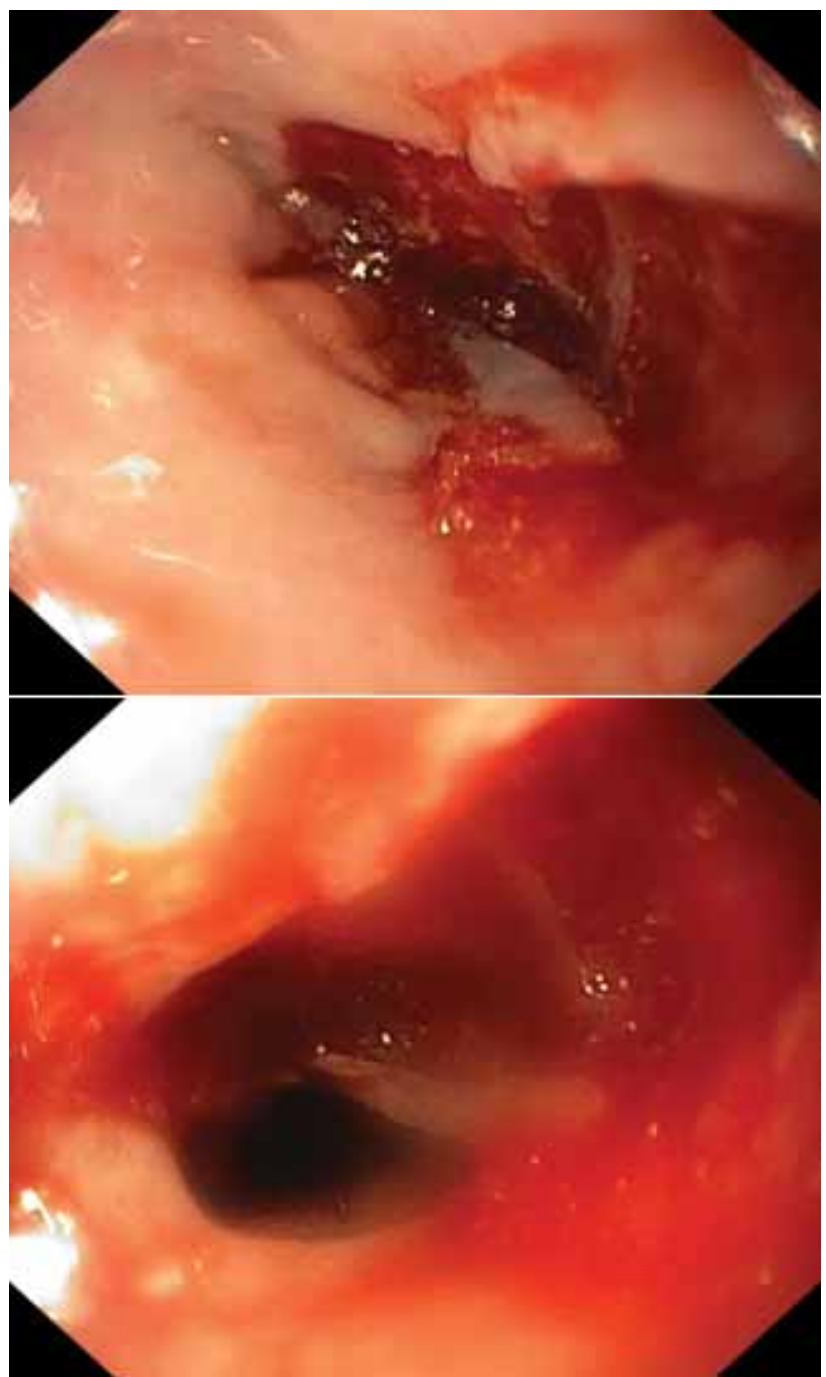

2. ábra hullámrajzolat, hosszú szakaszú strictura, hegek. Ezek a különböző minták együttesen is fennállhatnak ugyanannál a betegnél (1. ábra). Hirano és mtsai szorgalmazzák egy egységes endoszkópos pontrendszer bevezetését EoE-ben (Endoscopic Reference Score for EoE EREFS) [29, 30].

Konszenzus alapján, EoE-gyanú esetén, az endoszkópos vizsgálat során a proximalis és distalis nyelőcsőből is 2-4 biopsziás mintavétel javasolt a pontos diagnosztika érdekében. EoE-ben végzett endoszkópos vizsgálat során a vérzés és a perforáció kialakulásának veszélye jelentős, így fokozott körültekintést kíván a beavatkozást végző gasztroenterológustól (2. ábra) [24].

\section{Szövettan}

Egészséges nyelőcsőben nem találhatók eosinophil granulocyták, így a nyelőcső-nyálkahártyában jelentkező eosinophilia nem pathognomicus egyetlen betegségre sem. EoE-ben minden esetben fennálló nyelőcsőnyálkahártyaeosinophila akkor tekinthető diagnosztikus értékűnek, ha az eosinophil granulocyták száma eléri vagy meghaladja a 15 eosinophil granulocyta/nagy nagyítású látótér arányt (15 eog/nnl), és az emésztőrendszer további szakaszaiból vett biopsziás minták (gyomor, duodenum, colon) nem mutatnak érdemi eltérést. A kritérium gyermekekben és felnőttekben egyaránt érvényes [24].

\section{Allergiaellenes tesztek}

A legújabb konszenzuskonferencia ajánlása szerint EoEgyanús betegek esetében, mivel magas az EoE-vel egyidejúleg fennálló allergiás megbetegedések: asthma, rhinitis, atopiás dermatitis vagy ételallergia valószínúsége, allergológus vagy immunológus szakember bevonására lehet szükség a diagnosztikus folyamat során.

Egyidejűleg fennálló ételallergia vizsgálatára ajánlott elvégezni a szérum-IgE- és bőr-Prick-tesztet nutritív allergénekre. A konszenzus javasolja a szérum-IgE- és bőrPrick-teszt aeroallergénekre történő vizsgálatát is, mivel számos tanulmány igazolja az aeroallergének szenzitivizáló hatását és a tünetek évszakhoz kötött megjelenését újonnan diagnosztizált EoE-betegekben. Az aero- és nutritív allergénekre végzett két előbbi tesztet Patchteszttel kiegészítve (non-IgE-mediált immunreakciók kimutatása) javulhat az allergiavizsgálatok prediktív érteke.

Ugyanakkor a bőr-Prick- és Patch-teszt sem tudja sokszor azonosítani az elkerülendő ételallergéneket, így gyakran a beteg empirikus tapasztalataira kell hagyatkoznunk $[24,25]$.

\section{Nyelöcsö-pH-monitorozás}

$\mathrm{Az}$ EoE és GORB tünetei hasonlóak, GORB-ban is megfigyelhető az eosinophilgranulocyta-szám növekedése a nyelőcső nyálkahártyájában, valamint a két beteg- 
ség együttes fennállása is lehetséges. Egyes vizsgálatok szerint GORB fennállása elősegítheti EoE kialakulását. Nyelőcső-pH-monitorozás segít elkülöníteni egymástól a savhatás és az EoE által kiváltott eosinophiliát [31].

\section{Kezelés}

Az EoE kezelésében az elkerülő diéta, a gyógyszeres gyulladáscsökkentés és súlyos fokú szúkületek esetén a mechanikus tágítás játszik szerepet. Az EoE egész életen át tartó kezelést igénylő krónikus betegség, fenntartó terápia hiányában (diétahiba, szteroidkezelés leállítása) a tünetek fellángolása várható.

\section{Diéta}

Mivel az ételallergének meghatározó szerepet játszanak az EoE patomechanizmusában, így logikus, hogy az étrendből történő elhagyásuk az EoE terápiájának részét képezi. Az ajánlások háromféle diétát különböztetnek meg: elemi diéta, célzott „target” és az úgynevezett „six food" elkerülő diéta. Az étrendi diéták a szteroidkezelés hatékony alternatívájának tekinthetők. A diéta sikerének feltétele a beteg motiváltsága, jó compliance és dietetikussal történő többszöri konzultáció.

$\mathrm{Az}$ étrend megválasztásánál mindig ügyelnünk kell a megfelelő tápértékre és az esszenciális tápanyagok kellő mértékü bevitelére is [32].

\section{Elemi diéta}

Az elemi diéta aminosavakból, alapvető szénhidrátokból és közepes láncú trigliceridekből épül fel, az ételallergének teljes eliminálása révén fejti ki gyulladáscsökkentő hatását. EoE-ben szenvedő gyermekeknél alkalmazva a tünetek és a szövettani kép javulását eredményezte [33, 34]. Felnőtteknél a diéta kevésbé hatékony, a szövettani kép javulása nem járt együtt a tünetek eliminálásával, valamint felnőtt betegeknél a diétacompliance is alacsony. Hátránya, hogy a diéta drága, az íze miatt gyakran táplálószondát igényel, ami az életminőséget negatívan befolyásolja [35].

\section{Célzott „target” elkerülő diéta}

A diéta lényege, hogy az allergiavizsgálatok segítségével kiszűrrt ételallergéneket elimináljuk az étrendből. Az ezen a módszeren alapuló diéta sikeraránya gyermekekben 55 és 75\% közé tehető [36]. Wolf és mtsai 22 felnőtt beteg vizsgálata során a betegek 68\%-ánál a tünetek, 53\%-ánál a szövettan javulásáról számoltak be [37]. A diéta alkalmazhatóságát korlátozza, hogy a bőr-Prick-, illetve Patch-teszttel nem mindig sikerül maradéktalanul azonosítani az elkerülendő ételallergéneket [38].

\section{„Six food” elkerülő diéta}

Empirikus megközelítés alapján az étrendből a 6 leggyakoribb ételallergént (tej, tojás, szója, búza, mogyoró, tenger gyümölcsei) kizáró diéta. Gyermekekben és fel- nőttekben egyaránt hatékony: Gonsalves és mtsai által végzett vizsgálatban 6 hetes „six food” eliminációs diéta a felnőtt betegek 94\%-ában a tünetek, 64\%-ában a szövettan javulását eredményezte [39]. Az elkerülő diéta hatására bekövetkező szövettani remodellinget követően, egyes elkerült ételek étrendbe történő újbóli bevezetésével, meghatározhatjuk az EoE kialakulásában elsődleges szerepet játszó specifikus antigént. A vizsgálatok során a két leggyakoribb, legkevésbé tolerált ételallergénnek a tej és a búzafehérje bizonyult [32].

\section{Gyógyszeres kezelés}

\section{Protonpumpagátlók (PPI)}

A gyógyszeres kezelés első lépése a PPI-terápia, amely megszünteti a GORB okozta másodlagos nyelőcső-eosinophiliát és gyulladást, ami az EoE egyik trigger faktora is lehet. A PPI dózisa felnőtteknél $20-40 \mathrm{mg} /$ nap 8-12 héten keresztül adagolva, míg gyermekek esetében a dózis $1 \mathrm{mg} /$ ttkg napi 2-szer 8-12 héten keresztül. A legújabb kutatások szerint a PPI-terápia nemcsak az EoEvel szövődött GORB eliminálásában játszik szerepet, hanem az eotaxin-3-expresszió gátlása révén, az EoE egyik alcsoportjának tartott PPI-érzékeny eosinophil oesophagia gyógyításában is [40].

\section{Kortikoszteroidok}

A nyelőcsőgyulladás kezelésében a kortikoszteroidok, a flutikazon-propionát és budesonid jó eredményekkel alkalmazhatók a tünetek kezelésében és az eosinophilia csökkentésében. A szisztémás alkalmazás helyett a helyi, spray vagy orálisan is alkalmazható viszkózus forma javasolt. A két alkalmazás hatékonysága közel azonos, de az utóbbi kevesebb mellékhatással jár. Szisztémás szteroidot csak súlyos EoE-ben vagy a betegség akut exacerbatiója során alkalmazunk. A lokálisan adott flutikazon dózisa napi 2-szer 440-880 $\mu$ g, a budesonid dózisa 1-2 $\mathrm{mg} / \mathrm{nap}$ (gyermekekben: flutikazon 88-440 $\mu \mathrm{g}$ napi 2-4-szer, budesonid $1 \mathrm{mg} / \mathrm{ttkg} / \mathrm{nap}$ ). Használatuk előtt szükséges a szájüreg vízzel történő átöblítése, használatot követően pedig legalább 30 percig tilos étel vagy ital fogyasztása. Dellon és mtsai a viszkózus és a porlasztott kortikoszteroidok hatásosságát összehasonlítva EoE kezelésében azt találták, hogy a viszkózus forma jobban tapad a nyálkahártya felületére, és kevésbé jelenik meg a hatóanyag a tüdőben, így használata előnyösebb a porlasztott formával szemben $[24,41]$.

A szteroidkezelés hátránya, hogy nincs egyértelműen definiálható időtartama, átlagosan 6-12 hétig alkalmazzák, de a kezelés elhagyását követően 9 hónapon belül 90\%-ra tehető a relapsus valószínúsége. A lokális szteroiddal történő hosszú távú kezelés hatékonyságát illetően még nem áll rendelkezésünkre elég adat. A helyileg alkalmazott szteroidterápiát a betegek általában jól tolerálják, a leggyakoribb mellékhatás a nyelőcső-candidiasis $(0-32 \%)[31,39]$. 


\section{Egyéb gyógyszerek}

A leukotriénantagonista, asthmában is használatos montelukast az EoE tüneteit részben csökkentette, de a szövettani képben érdemi változást nem okozott [42]. A thiopurinokat egyes EoE-esetekben jó eredménnyel alkalmazták, de a kezelés végeztével a eosinophilia rövid időn belül ismételten kiújult [43].

A mepolizumab az IL-5 gátlásán keresztül képes hatni a Th2 immunválaszra. Straumann és mtsai egy placebokontrollos vizsgálatban 11 beteget 12 héten keresztül havonta egy alkalommal mepolizumabbal kezeltek, és ez a tünetek részleges javulásához, a perifériás és a nyelőcső-eosinophilia csökkenéséhez vezetett, jelenleg klinikai alkalmazása nem ismert [44].

\section{Mechanikus (ballonos) nyelöcsötágitás}

A diéta és gyógyszeres kezelés sikertelensége esetén az EoE második vonalbeli kezelése a kialakult szúkületek endoszkópos ballonos tágítása. Ez a terápiás módszer hatékonyan csökkenti a tüneteket, de nem szünteti meg a nyelőcső-eosinophiliát [45]. A mechanikus tágítás szövődménye lehet a beavatkozást követő mellkasi fájdalom, nyelőcsővérzés és -perforáció [46].

\section{Következtetések}

Az eosinophil oesophagitis a nyelőcső krónikus, antigénmediált gyulladása. Genetikailag fogékony egyénekben, orális és/vagy aeroantigének triggerelőhatására a nyelőcső eosinophil granulocytáinak infiltrációjához, nyálkahártya-hyperplasiához és a subepithelialis rétegek fibrosisához vezet. Gyermek- és felnőttkorban egyaránt jelentkezhet, kétharmados férfi dominancia jellemzi. A betegség gyakran társul más allergiás kórképekkel.

A klinikai tünetek életkorfüggőek: gyermekekben táplálási nehézség, növekedéselmaradás, GORB-szerú tünetek dominálnak, felnőttekben az időszakosan jelentkezó dysphagia és falatelakadás a legjellemzőbb tünet.

Az EoE fó diagnosztikus eszközei az endoszkópia és a szövettan. Endoszkópos eltérések EoE-ben: pontszerú exudatum, nyálkahártya-barázdák, gyưrúképződés, krepp-papír-, utcakő- és hullámrajzolat, strictura, hegek. EoE-ben a szövettan $15 \mathrm{eog} / \mathrm{nnl}$ esetén diagnosztikus értékư. Egyidejűleg fennálló étel- és aeroallergia vizsgálatára ajánlott elvégezni a szérum-IgE, bőr-Prick- és Patch-tesztet nutritív és aeroantigénre.

$\mathrm{Az}$ EoE egész életen át tartó kezelést igénylő krónikus betegség. Terápiája lehet gyógyszeres gyulladáscsökkentés: PPI-terápia, szisztémás vagy lokális kortikoszteroidkezelés (budesonid, flutikazon). A gyógyszer elhagyását követően gyakori a relapsus. A gyógyszeres kezelés alternatívái a trigger antigének étrendből történő eltávolításán alapuló diéták: az étrendből az összes ételallergént kiiktató eliminációs diéta, az allergiatesztek által meghatározott allergéneket elimináló „target” diéta és a 6 leggyakoribb nutritív allergént az étrendból elhagyó „six food" elkerülő diéta. A diéta bevezetése előtt dietetikussal történő konzultáció szükséges.

Az első vonalbeli kezelések hatástalansága esetén a kialakult szúküuleteket mechanikus módon endoszkópos ballon segítségével tágítjuk fel, ennek az eljárásnak gyakori szövődménye a nyelőcső-perforáció.

Anyagi támogatás: A közlemény megírása anyagi támogatásban nem részesült.

Szerzői munkamegosztás: K. D., J. M.: Irodalomkutatás és a kézirat megszövegezése. J. M.: Endoszkópos ábrák készítése. T. Zs.: A kézirat felülvizsgálata, megszövegezése. A cikk végleges változatát mindhárom szerző elolvasta és jóváhagyta.

Érdekeltségek: A szerzőknek nincsenek érdekeltségeik.

\section{Irodalom}

[1] Philpott, H., Nandurkar, S., Thien, F., et al.: Eosinophilic esophagitis: a clinicopathological review. Pharmacol. Ther., $2015,146,12-22$.

[2] Sperry, S. L., Woosley, J. T., Shaheen, N. J., et al.: Influence of race and gender on the presentation of eosinophilic esophagitis. Am. J. Gastroenterol., 2012, 107(2), 215-221.

[3] Noel, R. J., Putnam, P. E., Rothenberg, M. E.: Eosinophilic esophagitis. N. Engl. J. Med., 2004, 351(9), 940-841.

[4] DeBrosse, C. W., Collins, M. H., Buckmeier Butz, B. K., et al.: Identification, epidemiology, and chronicity of pediatric esophageal eosinophilia, 1982-1999. J. Allergy Clin. Immunol., 2010, 126(1), 112-119.

[5] Soon, I. S., Butzner, J. D., Kaplan, G. G., et al.: Incidence and prevalence of eosinophilic esophagitis in children. J. Pediatr. Gastroenterol. Nutr., 2013, 57(1), 72-80.

[6] Kapel, R. C., Miller, J. K., Torres, C., et al.: Eosinophilic esophagitis: a prevalent disease in the United States that affects all age groups. Gastroenterology, 2008, 134(5), 1316-1321.

[7] Whitney-Miller, C. L., Katzka, D., Furth, E. E.: Eosinophilic esophagitis: a retrospective review of esophageal biopsy specimens from 1992 to 2004 at an adult academic medical center. Am. J. Clin. Pathol., 2009, 131(6), 788-792.

[8] Veerappan, G. R., Perry, J. L., Duncan, T. J., et al.: Prevalence of eosinophilic esophagitis in an adult population undergoing upper endoscopy: a prospective study. Clin. Gastroenterol. Hepatol., 2009, 7(4), 420-426.el-e2.

[9] Almansa, C., Krishna, M., Buchner, A. M., et al.: Seasonal distribution in newly diagnosed cases of eosinophilic esophagitis in adults. Am. J. Gastroenterol., 2009, 104(4), 828-833.

[10] Croese, J., Fairley, S. K., Masson, J. W., et al.: Clinical and endoscopic features of eosinophilic esophagitis in adults. Gastrointest. Endosc., 2003, 58(4), 516-522.

[11] Sant'Anna, A. M., Rolland, S., Fournet, J. C., et al.: Eosinophilic esophagitis in children: symptoms, histology and $\mathrm{pH}$ probe results. J. Pediatr. Gastroenterol. Nutr., 2004, 39(4), 373-377.

[12] Rothenberg, M. E., Spergel, J. M., Sherrill, J. D., et al.: Common variants at $5 \mathrm{q} 22$ associate with pediatric eosinophilic esophagitis. Nat. Genet., 2010, 42(4), 289-291.

[13] Liu, .. J.: TSLP in epithelial cell and dendritic cell cross talk. Adv. Immunol., 2009, 101, 1-25.

[14] Kagalwalla, A. F., Sentongo, T. A., Ritz, S., et al.: Effect of sixfood elimination diet on clinical and histologic outcomes in eosinophilic esophagitis. Clin. Gastroenterol. Hepatol., 2006, $4(9), 1097-1102$. 
[15] Mishra, A., Schlotman, J., Wang, M., et al.: Critical role for adaptive $\mathrm{T}$ cell immunity in experimental eosinophilic esophagitis in mice. J. Leukoc. Biol., 2007, 81(4), 916-924.

[16] Arora, A. S., Yamazaki, K.: Eosinophilic esophagitis: asthma of the esophagus? Clin. Gastroenterol. Hepatol., 2004, 2(7), 523530 .

[17] Lippai, D., Tulassay, Z.: Eosinophilic esophagitis. [Eosinophil oesophagitis.] Orv. Hetil., 2010, 151(30), 1225-1231. [Hungarian]

[18] Raheem, M., Leach, S. T., Day, A. S., et al.: The pathophysiology of eosinophilic esophagitis. Front. Pediatr., 2014, 2, 41.

[19] Blanchard, C., Stucke, E. M., Rodriguez-Jimenez, B., et al.: A striking local esophageal cytokine expression profile in eosinophilic esophagitis. J. Allergy Clin. Immunol., 2011, 127(1), 208-217.

[20] Blanchard, C., Stucke, E. M., Burwinkel, K., et al.: Coordinate interaction between IL-13 and epithelial differentiation cluster genes in eosinophilic esophagitis. J. Immunol., 2010, 184(7), 4033-4041.

[21] Fillon, S., Robinson, Z. D., Colgan, S. P., et al.: Epithelial function in eosinophilic gastrointestinal diseases. Immunol. Allergy Clin. North Am., 2009, 29(1), 171-178.

[22] Mishra, A., Hogan, S. P., Brandt, E. B., et al.: An etiological role for aeroallergens and eosinophils in experimental esophagitis. J. Clin. Invest., 2001, 107(1), 83-90.

[23] Furuta, G. T., Liacouras, C. A., Collins, M. H., et al.: Eosinophilic esophagitis in children and adults: a systematic review and consensus recommendations for diagnosis and treatment. Gastroenterology, 2007, 133(4), 1342-1363.

[24] Liacouras, C. A., Furuta, G. T., Hirano, I., et al.: Eosinophilic esophagitis: updated consensus recommendations for children and adults. J. Allergy Clin. Immunol., 2011, 128(1), 3-20.e6.

[25] Straumann, A.: Clinical evaluation of the adult who has eosinophilic esophagitis. Immunol. Allergy Clin. North Am., 2009, 29(1), 11-18

[26] Katzka, D. A.: Demographic data and symptoms of eosinophilic esophagitis in adults. Gastrointest. Endosc. Clin. N. Am., 2008, $18(1), 25-32$.

[27] Thompson, D. M., Orvidas, L. J.: Otorhinolaryngologic manifestations of eosinophilic esophagitis. Gastrointest. Endosc. Clin. N. Am., 2008, 18(1), 91-98.

[28] Roman, S., Savarino, E., Savarino, V., et al.: Eosinophilic oesophagitis: from physiopathology to treatment. Dig. Liver Dis., 2013, 45(11), 871-878

[29] Mackenzie, S. H., Go, M., Chadwick, B., et al.: Eosinophilic oesophagitis in patients presenting with dysphagia - a prospective analysis. Aliment. Pharmacol. Ther., 2008, 28(9), 1140-1146.

[30] Hirano, I., Moy, N., Heckman, M. G., et al.: Endoscopic assessment of the oesophageal features of eosinophilic oesophagitis: validation of a novel classification and grading system. Gut, 2013, 62(4), 489-495

[31] Dellon, E. S., Gibbs, W. B., Fritchie, K. J., et al.: Clinical, endoscopic, and histologic findings distinguish eosinophilic esophagitis from gastroesophageal reflux disease. Clin. Gastroenterol. Hepatol., 2009, 7(12), 1305-1313.
[32] Turnbull, J. L., Adams, H. N., Gorard, D. A.: Review article: the diagnosis and management of food allergy and food intolerances. Aliment. Pharmacol. Ther., 2015, 4l(1), 3-25.

[33] Kelly, K. J., Lazenby, A. J., Rowe, P. C., et al.: Eosinophilic esophagitis attributed to gastroesophageal reflux: improvement with an amino acid-based formula. Gastroenterology, 1995, 109(5), 1503-1512.

[34] Markowitz, J. E., Spergel, J. M., Ruchelli, E., et al.: Elemental diet is an effective treatment for eosinophilic esophagitis in children and adolescents. Am. J. Gastroenterol., 2003, 98(4), 777-782.

[35] Peterson, K. A., Byrne, K. R., Vinson, L. A., et al.: Elemental diet induces histologic response in adult eosinophilic esophagitis. Am. J. Gastroenterol., 2013, 108(5), 759-766.

[36] Liacouras, C. A., Spergel, J. M., Ruchelli, E., et al.: Eosinophilic esophagitis: a 10-year experience in 381 children. Clin. Gastroenterol. Hepatol., 2005, 3(12), 1198-1206.

[37] Wolf, W. A., Jerath, M. R., Sperry, S. L., et al.: Dietary elimination therapy is an effective option for adults with eosinophilic esophagitis. Clin. Gastroenterol. Hepatol., 2014, 12(8), 12721279.

[38] Aceves, S. S.: Food allergy testing in eosinophilic esophagitis: what the gastroenterologist needs to know. Clin. Gastroenterol. Hepatol., 2014, 12(8), 1216-1223.

[39] Gonsalves, N., Kahrilas, P. J.: Eosinophilic oesophagitis in adults. Neurogastroenterol. Motil., 2009, 21(10), 1017-1026.

[40] Zhang, X., Cheng, E., Huo, X., et al.: Omeprazole blocks STAT6 binding to the eotaxin-3 promoter in eosinophilic esophagitis cells. PLoS ONE, 2012, 7(11), e50037.

[41] Dellon, E. S., Sheikh, A., Speck, O., et al.: Viscous topical is more effective than nebulized steroid therapy for patients with eosinophilic esophagitis. Gastroenterology, 2012, 143(2), 321-324.el.

[42] Lucendo, A. J., De Rezende, L. C., Jiménez-Contreras, S., et al.: Montelukast was inefficient in maintaining steroid-induced remission in adult eosinophilic esophagitis. Dig. Dis. Sci., 2011, 56(12), 3551-3558.

[43] Netzer, P., Gschossmann, J. M., Straumann, A., et al.: Corticosteroid-dependent eosinophilic oesophagitis: azathioprine and 6-mercaptopurine can induce and maintain long-term remission. Eur. J. Gastroenterol. Hepatol., 2007, 19(10), 865-869.

[44] Straumann, A.: Treatment of eosinophilic esophagitis: diet, drugs, or dilation? Gastroenterology, 2012, 142(7), 1409-1411.

[45] Ali, M. A., Lam-Himlin, D., Voltaggio, L.: Eosinophilic esophagitis: a clinical, endoscopic, and histopathologic review. Gastrointest. Endosc., 2012, 76(6), 1224-1237.

[46] Cohen, M. S., Kaufman, A. B., Palazzo, J. P., et al.: An audit of endoscopic complications in adult eosinophilic esophagitis. Clin. Gastroenterol. Hepatol., 2007, 5(10), 1149-1153.

(Kocsis Dorottya dr., Budapest, Szentkirályi u. 46., 1088 e-mail: kocsisdorottyal@gmail.com) 